Колупасва Тетяна

кандидат педагогічних наук, доцент, професор кафедри педагогіки початкової освіти Рівненського державного гуманітарного університету, м. Рівне, Україна ORCID: 0000-0003-0164-0926 e-mail: kolupaeva.tatyana@gmail.com

Міщеня Оксана кандидат педагогічних наук, доцент, доцент кафедри педагогіки початкової освіти Рівненського державного гуманітарного університету, м. Рівне, Україна ORCID: 0000-0003-3041-1575 e-mail: oksanamishchenia@gmail.com

Третяк Оксана кандидат педагогічних наук, доцент кафедри педагогіки початкової освіти Рівненського державного гуманітарного університету, м. Рівне, Україна ORCID: 0000-0002-4558-2863 e-mail: ksenijat2017@gmail.com

\title{
РОЛЬ ІНТЕРАКТИВНИХ ТЕХНОЛОГІЙ НАВЧАННЯ В ОСОБИСТІСНО-ОРІЕНТОВАНІЙ ПІДГОТОВЦІ МАЙБУТНІХ УЧИТЕЛІВ ПОЧАТКОВОЇ ШКОЛИ
}

\begin{abstract}
Анотація. Стаття присвячена ролі інтерактивних технологій навчання в особистісно-орієнтованій підготовці майбутніх учителів початкової школи. На основі аналізу та узагальнення педагогічної літератури з'ясовано, що інтерактивне навчання - це навчання, яке відбувається за умови постійної, активної взаємодії всіх учасників навчального процесу. Це співнавчання, взаємонавчання (колективне, групове, навчання у співпраці), де всі учасники $є$ рівноправними суб'єктами навчального процесу, розуміють, що вони роблять, рефлексують з приводу того, що вони знають, вміють здійснювати. Організація інтерактивного навчання передбачає моделювання різноманітних життєвих ситуацій, спільне вирішення проблем на основі аналізу обставин та відповідної ситуації, використання рольових ігор. Проаналізовано різні підходи щодо класифікації інтерактивних методів навчання. Доведено, що інтерактивні методи навчання сприяють інтенсифікації навчального процесу та активізації навчально-пізнавальної діяльності студентів, майбутніх учителів початкової школи. У статті особливо наголошується на ефективності перелічених форм організації спілкування на семінарських заняттях, на соціальній значущості гуманістичного потенціалу, який неодмінно трансформується через творчу працю в наступній діяльності майбутніх учителів початкової школи у демократичні когнітивні та поведінкові норми.
\end{abstract}

с Колупаєва Т., Міщеня О.,

Третяк О., 2019 
Ключові слова: інтерактивні технології навчання, особистісно-орієнтована освіта, дискусійні методи, групова дискусія, аналіз життєвих ситуацій, ігрові методи, імітаційні методи.

Постановка проблеми. Прискорення темпу життя, великий потік знань, що впливає на сучасну людину, потребує від неї вміння швидко знаходити необхідне рішення, використовуючи для цього пошукові методи, користуючись великою кількістю різноманітних джерел інформації. У зв'язку з цим, серед традиційних форм та методик навчання, у педагогічній практиці все частіше використовуються інтерактивні методи. Ця потреба пояснюється тим, що таке навчання спрямоване на підвищення пізнавальної активності студентів, посилення діяльнісного підходу в навчанні і реалізацію спільної діяльності, спрямованої на кооперативну обробку навчальної інформації 3 виробленням нових знань особисто кожним студентом в оптимальному, тільки для нього, режимі. Інтерактивні методи навчання досить швидко були визнані вчителями та управлінцями дієвим засобом впровадження нових освітніх технологій. Однак використання їх у практиці підготовки майбутніх учителів початкової школи поки що фрагментарне, епізодичне, не системне.

Інтерактивний - означає можливість взаємодіяти або знаходитись у режимі бесіди, діалогу з чим-небудь або ким-небудь. Отже, інтерактивне навчання - це, насамперед, діалогове навчання, під час якого здійснюється взаємодія учителя і учня, викладача та студента.

Суть інтерактивного навчання полягає в тому, що навчальний процес організований у такий спосіб, коли практично всі студенти беруть участь у процесі пізнання. Вони мають змогу розуміти і рефлексувати 3 приводу отриманих знань та вміють реалізувати їх в процесі активної діяльності.

Аналіз останніх досліджень 3 проблеми. Основним проблемам освітньої інноватики в сучасній теорії і практиці присвячені роботи Л. Буркової, Л. Ващенко, Л. Даниленко, Д. Джонсона, П. Дроб'язка, . Дусавицького, В. Живодьора, О. Козлової, М. Крюгера, Дж. Мейерса, А. Підласого, Н. Погрібної, О. Попової, І. Пригожина, Г. Селевка, К. Ушакова, Н. Федорової, А. Хуторського.

Аналіз праць сучасних дослідників засвідчує, що висвітленню сутності інтерактивного навчання, особливостей і способів його реалізації присвячені роботи О. Пометун, Л. Пироженко та інших.

До використання інтерактивних методів навчання безпосередньо в початковій школі звертаються В. Мазай, Д. Мазоха, О. Мазур, Н. Мельник, А. Соценко, О. Стребна та інші.

Мета статті. Незважаючи на наявність численних досліджень у сфері інтерактивних технологій, інтерактивне навчання досі не набуло широкої популярності при підготовці майбутніх учителів початкової школи. Стаття присвячена аналізу теорії i практичній діяльності 3 впровадження інтерактивних технологій в навчальний процес підготовки майбутнього вчителя початкової школи.

Виклад основного матеріалу дослідження. Особистісно-орієнтована освіта передбачає впровадження нових педагогічних технологій та ефективних форм взаємодії з усіма учасниками навчального процесу на засадах глибокої поваги до особистості, урахування особливостей індивідуального розвитку, ставлення до учасників як до свідомих відповідальних суб'єктів навчально- 
виховної взаємодії; передбачає формування цілісної особистості, яка усвідомлює свою гідність і поважає інших людей (Фіцула, 2007).

На початку третього тисячоліття над проблемами особистісноорієнтованого навчання працюють психологи і педагоги, зокрема Г. Балл, I. Бех, О. Бондаревська, С. Кульневич， О. Пєхота， С. Подмазін， В. Рибалка, В. Сєриков, А. Хуторський, І. Якиманська та інші.

Водночас, І. Бех вважає, що особистісно орієнтований навчальновиховний процес не стільки задає вектор розвитку, скільки створює для цього всі необхідні умови. Його мета полягає не в плануванні загальної лінії розвитку, а в тому, щоб допомогти кожній особистості, враховуючи ії досвід пізнання, удосконалювати свої індивідуальні здібності, розвиватися (Антонів, 2013).

Зокрема, С. Подмазін зазначає, що мета особистісно-орієнтованої освіти полягає в створенні оптимальних умов для розвитку й становлення особистості як суб'єкта діяльності і суспільних відносин, яка здійснює їх відповідно до стійкої ієрархічної системи гуманістичних особистісних цінностей (Пометун, 2004).

Саме особистісно-орієнтований підхід забезпечує створення нових механізмів навчання і виховання та грунтується на принципах глибокої поваги до особистості та врахуванні індивідуальних особливостей.

Мета i завдання особистісно-орієнтованого навчання полягають у створенні максимально сприятливих умов для розвитку i саморозвитку особистості, виявленні та активному використанні його індивідуальних особливостей у навчальній діяльності.

Особистісно-орієнтована модель навчання передбачає також розвиток критичного мислення студентів, що потребує неодмінно діалогічної ситуації, вільної, творчої діяльності. Тільки людина, яка вільно, активно і критично мислить, може об'єктивно оцінити події, зробити правильні висновки, досягти успіхів у різноманітних сферах діяльності.

Важливе місце в особистісно-орієнтованому навчанні посідають інтерактивні технології.

Інтерактивні технології навчання відносяться до педагогічних технологій, побудованих на основі гуманізації й демократизації педагогічних відносин, активізації діяльності студентів та ефективності організації і управління навчальним процесом. Ці технології навчання характеризуються як розвиваючі, діалогічні, комунікативні, ігрові та творчі.

Інтерактивні технології - це організація засвоєння знань і формування певних умінь та навичок через сукупність особливим способом організованих навчально-пізнавальних дій, що полягають у активній взаємодії учнів між собою та побудові міжособистісного спілкування 3 метою досягнення запланованого результату (Пометун, 2004).

Зокрема, інтерактивні методи - це організація навчання, при якій студенту неможливо не брати участь у колективному, взаємодоповнюючому, заснованому на взаємодії всіх учасників процесу навчального пізнання. Метою застосування інтерактивних методів $є$ не тільки спонукання до активної роботи, а й ініціація творчості, розвитку комунікативних навичок тощо (Пометун, 2007). 
Оскільки метод $є$ складовою ширшого поняття «технологія навчання», доцільно диференціювати інтерактивні методи навчання відповідно до класифікацій інтерактивних технологій.

Класифікації інтерактивних методів навчання досить різноманітні. Над ними працювали такі вченні, як Л. Вавилова, Т. Добриніна, Є. Голант, О. Голубкова, В. Гузєв та інші.

Розглядаючи різні класифікації інтерактивних методів, потрібно звернути увагу на такі проблеми: по-перше, ще досі не було створено жодної повної класифікації інтерактивних методів навчання. По-друге, немає чіткого розмежування між інтерактивними та активними методами навчання. Одні і ті ж види відносять як до активних, так і до інтерактивних.

Організація інтерактивного навчання передбачає моделювання життєвих ситуацій, використання рольових ігор, спільне вирішення проблеми на основі аналізу обставин та відповідної ситуації. Цей метод ефективно сприяє формуванню навичок і вмінь, виробленню цінностей, створенню атмосфери співробітництва, взаємодії, дає змогу педагогу стати активним організатором творчої роботи колективу.

Під час інтерактивного навчання студент стає не об'єктом, а суб'єктом навчання, він відчуває себе активним учасником подій і власної освіти та розвитку. Це забезпечує внутрішню мотивацію навчання, що сприяє його ефективності, зростає цікавість до процесу навчання. Інтерактивні методи навчання є частиною особистісно-зорієнтованого навчання, оскільки сприяють соціалізації особистості, усвідомленню себе як частини колективу, своєї ролі і потенціалу.

До прикладу, Г. Харханова класифікує інтерактивні методи на основі формування мотивації конфлікту на три групи залежно від спектру можливостей: інтерактивні методи навчання 3 широким, середнім і вузьким спектром можливостей (Новолокова, 2014).

О. Єльникова, I. Кефелі класифікують інтерактивні методи навчання на основі їх комунікативних функцій, розділяючи їх на три групи: дискусійні методи (діалог, групова дискусія, аналіз життєвих ситуацій); ігрові методи (дидактичні ігри, творчі ігри, в тому числі ділові, рольові ігри, організаційнодіяльнісні ігри, контрігри); психологічні групи інтерактивних методів (сенситивний і комунікаційний тренінг, емпатія) (Павелків, 2008).

Зі свого боку, Л. Кратясюк та Г. Кулініч класифікують ігрові інтерактивні методи навчання за функціями: ігри за правилами (настільні, рухливі, комп'ютерні); творчі ігри (рольові, ігри-змагання, комп'ютерні). За дидактичними цілями виділяють ігри, спрямовані на вивчення нового матеріалу; ігри, спрямовані на перевірку знань; ігри, метою яких є закріплення і узагальнення пройденого матеріалу (Кратясюк, 2004).

Т. Паніна, Л. Вавилова класифікують інтерактивні методи навчання за трьома групами: дискусійні (діалог, групова дискусія, розбір ситуацій 3 практики); ігрові (дидактичні творчі ігри, рольові ігри, організаційнодіяльнісні ігри); тренінгові (комунікативні тренінги, тренінги сенситивності) (Косяк, 2013).

О. Січкарук пропонує розділити інтерактивні методи на дві групи:

1) спілкування відбувається між педагогом і студентами;

2) спілкування відбувається між студентами. 
До першої групи автор включає лекції, які містять елементи бесіди, дискусії, проблемні лекції, семінари-обговорення, семінари «питаннявідповідь», дискусії із проблемними запитаннями, консультації (особливо при дистанційному навчанні), роботу через сайт-курс.

До другої - бесіди, дискусії, круглі столи, «мозковий штурм», групове вирішення конкретних ситуацій, ділові, рольові та дидактичні ігри, бізнессимуляції, проекти, панельні вправи.

Отже, ігрові інтерактивні методи навчання включають:

- імітаційні методи, до яких відносяться: рольові ігри, що підрозділяються на ігри-драматизації і рольові дискусії; навчальні ділові ігри, що включають операційні та імітаційні ділові ігри;

- неімітаційні ігрові інтерактивні методи навчання представлені: дослідницькими діловими іграми; кейс-методами; проектними методами; організаційно-діяльнісними іграми (організаційно-розумові, моделюючі, проектні гри); аналізом конкретних ситуацій (аналіз мікроситуацій, аналіз ситуацій-ілюстрацій, аналіз ситуацій-проблем, розбір і обговорення конкретного матеріалу, вивчення передового досвіду і обмін знаннями); тренінговими методами (тренінг сенситивності, комунікативний тренінг, відеотренінг).

Неігрові інтерактивні методи навчання представлені методами діалогічної взаємодії: дебати, диспути, відкриті форуми, різні види дискусій («Круглий стіл», проблемна дискусія, експрес-дискусія, «Акваріум», «Ліберальний клуб», текстова дискусія). А також методами автентичного оцінювання досягнень студентів (портфоліо) (Радченко, 2012).

За запропонованою А. Смолкіним класифікацією методів активного навчання розрізняють імітаційні методи активного навчання, тобто форми проведення занять, у яких навчально-пізнавальна діяльність побудована на імітації професійної діяльності.

Імітаційні методи розподіляють на ігрові та неігрові. До ігрових відносять проведення ділових ігор, ігрового проектування, а до неігрових аналіз конкретних ситуацій, вирішення ситуаційних та інших завдань.

До ігрових імітаційних форм також відносяться: стажування 3 виконанням посадової ролі - форма й метод активного навчання конкретного типу, при якому моделлю виступає сама дійсність, а імітація стосується, в основному, виконання певної ролі (посади). При цьому розігрування ролей (інсценівка) - ігровий спосіб аналізу конкретних ситуацій, в основі яких лежать проблеми взаємин у колективі, вдосконалення стилю та методів керівництва.

Ігрове проектування - практичне заняття, суть якого складається в розробці конструкторського, технологічного й іншого видів проектів в ігрових умовах, що максимально відтворюють реальність.

Дидактична гра - це модель, тобто заміщення реально існуючого об'єкта, процесу, явища, яке здійснюється за допомогою різних засобів.

Інтерактивні технології навчання О. Пометун, Л. Пироженко розподілили на чотири групи: парне навчання (робота учня з вчителем чи однокласником один на один), фронтальне навчання, навчання у грі, навчання у дискусії (Пометун, 2004). 
До групового (кооперативного) навчання можна віднести: роботу в парах, ротаційні трійки, «Два-чотири-всі разом», «Карусель», роботу в малих групах, «Акваріум».

Під час роботи в парах можна виконувати такі вправи: обговорити завдання, короткий текст; взяти інтерв'ю, визначити ставлення (думку) партнера до цього питання, твердження і т. п.; зробити критичний аналіз роботи один одного; сформувати підсумок розглянутої теми тощо.

До фронтальних технологій інтерактивного навчання відносять такі, що передбачають одночасну спільну роботу всього колективу. Серед них: обговорення проблеми у загальному колі (iі застосовують 3 іншими технологіями), «Мікрофон» (надається можливість кожному сформулювати власне бачення та висловити свою думку чи позицію), незакінчені речення (поєднується 3 вправою «Мікрофон»), «Мозковий штурм» (інтерактивна технологія колективного обговорення широко використовується для прийняття кількох рішень 3 конкретної проблеми), «Навчаючи-вчуся», «Ажурна пилка», «Case-метод», «Дерево рішень» (Комар, 2006).

Обговорення проблеми в колективі - це технологія, яка застосовується, як правило, в комбінації з іншими. Її метою $є$ прояснення певних положень, привертання уваги всіх учасників до складних або проблемних питань у навчальному матеріалі, мотивація пізнавальної діяльності, актуалізація опорних знань тощо.

Різновидом загальногрупового обговорення $є$ технологія «Мікрофон», яка надає можливість кожному почергово висловитись, відповідаючи на запитання або з'ясувати свою думку чи позицію.

Прийом «Незакінчені речення» часто поєднується з «Мікрофоном» і дає можливість грунтовніше працювати над формою висловлення власних ідей, порівнювати їх з іншими. Робота за такою методикою дає присутнім змогу долати стереотипи, вільніше висловлюватися щодо запропонованих тем, відпрацьовувати вміння говорити коротко, але по суті та переконливо.

Інтерактивна технологія «Мозковий штурм» широко використовується для вироблення кількох варіантів з вирішення конкретної проблеми. Мозковий штурм спонукає студентів проявляти уяву та творчість, дає можливість їм вільно висловлювати свої думки. Мета «мозкового штурму» чи «мозкової атаки» в тому, щоб зібрати якомога більше ідей щодо проблеми від усіх учасників протягом обмеженого періоду часу.

Метод «Навчаючи - учусь» використовується при вивченні блоку інформації або при узагальненні та повторенні вивченого. Він дає можливість студентам взяти участь у передачі своїх знань одногрупникам. Використання цього методу підвищує інтерес до навчання.

Технологія «Ажурна пилка» («Мозаїка») використовується для створення на занятті ситуації, яка дає змогу студентам працювати разом для засвоєння великої кількості інформації за короткий проміжок часу. Цю технологію можна використовувати також у тих випадках, коли початкова інформація має бути донесена до студентів перед проведенням основного заняття або як додатковий матеріал до теми. Загалом, все це заохочує студентів допомагати один одному у навчанні.

Технологія «Аналіз ситуації» вчить студентів ставити запитання, відрізняти факти від гіпотез, виявляти важливі та другорядні обставини, аналізувати і приймати правильні рішення. 
Метою застосування технології «Вирішення проблем» $\epsilon$ навчити студентів самостійно вирішувати проблеми та приймати колективне рішення. Як варіант технології вирішення проблем можна використати «Дерево рішень», яке допомагає студентам проаналізувати та краще зрозуміти механізми прийняття складних рішень (Коротаєва, 2014)

До технологій навчання у грі відносяться імітації, рольові ігри, драматизація. Учасники навчального процесу, за ігровою моделлю, перебувають в інших умовах, аніж у традиційному навчанні. Учасникам надають максимальну можливість інтелектуальної діяльності, що обмежується лише конкретними правилами гри. Учасники самі обирають свою роль у грі, висуваючи припущення про ймовірний розвиток подій, створюють проблемну ситуацію, шукають шляхи ії розв'язання, покладаючи на себе відповідальність за обране рішення. Педагог в ігровій моделі виступає як: інструктор (ознайомлення з правилами гри, консультації під час іії проведення), суддярефері (коригування і поради стосовно розподілу ролей), тренер (підказки учасникам 3 метою прискорення проведення гри), головуючий, ведучий (організатор обговорення).

Розрізняють три сфери застосування ігрового методу:

1. Навчальна сфера: навчальний метод застосовується в процесі навчання, підвищення кваліфікації.

2. Дослідницька сфера: використовується для моделювання майбутньої професійної діяльності 3 метою вивчення прийняття рішень, оцінки ефективності організаційних структур і т. ін.

3. Оперативно-практична сфера: ігровий метод використається для аналізу елементів конкретних систем, для розробки різних елементів системи утворення (Антонів, 2013).

Педагогічна суть ділової гри - активізувати мислення майбутніх учителів, підвищити самостійність, внести дух творчості в процесі навчання.

Цей метод розкриває особистісний потенціал студента: кожен учасник може продіагностувати свої можливості поодинці, а також у спільній діяльності з іншими учасниками.

Ділова гра - це контрольована система, тому що процедура гри готується і коректується педагогом. Якщо гра проходить у планованому режимі, викладач може не втручатися в ігрові відносини, а тільки спостерігати й оцінювати ігрову діяльність студентів. Однак, якщо дії виходять за межі плану, зривають мету заняття, педагог може відкоригувати спрямованість гри і іiі емоційний настрій (Коваленко, 2013).

Перед проведенням ділової гри рекомендують проводити імітаційні вправи, які ближчі до навчальних ігор. Їх мета - надати студентам можливість в процесі творчої діяльності закріпити певні навички, акцентувати увагу на відповідному важливому понятті, категорії, законі. В умові виконання вправи обов'язково має бути протиріччя, тобто в імітаційній вправі має бути присутній елемент проблемності.

Після імітаційних вправ можна переходити до ділових ігор. У навчальному процесі 3ВО - це рольова гра, оскільки студенти ще не володіють повною мірою своєю спеціальністю. Мета цієї гри - сформувати певні навички й уміння студентів у їх активному творчому процесі. Соціальна значущість ділової гри полягає в тому, що в процесі вирішення певних завдань 
активізуються не лише знання, але й розвиваються колективні форми спілкування.

Вагоме місце серед інших методів навчання посідають дискусійні методи. Елементи дискусії (диспути, зіткнення позицій, навмисного загострення й навіть перебільшення протиріч в обговорюваному змістовному матеріалі) можуть бути використані в будь-яких організаційних формах навчання. В останньому випадку бажано, аби учасники дискусії представляли певні групи, що запускає в хід соціально-психологічні механізми формування ціннісноорієнтовної єдності, які підсилюють або навіть породжують нові мотиви діяльності (Іванішена, 2006).

Предметом дискусії можуть бути не тільки змістовні проблеми, але й моральні, а також міжособистісні відносини самих учасників групи. Результати таких дискусій (особливо коли створюються конкретні ситуації морального вибору) набагато сильніше модифікують поведінку людини, ніж просте засвоєння деяких моральних норм на рівні знання. Отже, дискусійні методи виступають як засіб не лише навчання, але й виховання.

Метою застосування методу «ПРЕС» $є$ навчання студентів знаходити та формулювати аргументи, висловлювати думки 3 дискусійного питання у виразній і стилістичній формі, переконувати інших.

Метод «Займи позицію» демонструє різноманіття поглядів на проблему, що вивчатиметься, або після опанування студентами певною інформацією стосовно неї з усвідомленням можливості протилежних позицій щодо іiі вирішення.

Інтерактивна технологія «Зміни позицію» $є$ подібною до попередньої. Вона також дає можливість обговорити дискусійні питання за участі всіх студентів. Метод дозволяє пристати на точку зору іншої людини, розвивати навички аргументації, активного слухання.

Водночас, однією з форм обговорення дискусійних питань $є$ технологія «Неперервна школа думок» (Нескінченний ланцюжок), метою якої є розвиток у студентів навичок прийняття особистого рішення та вдосконалення вміння аргументувати свою думку.

Прийом «Дискусія» - це широке публічне формулювання та обговорення певного дискусійного питання. Вона $\epsilon$ важливим засобом пізнавальної діяльності, сприяє розвитку критичного мислення студентів, дає можливість визначити власну позицію, формує навички аргументації та відстоювання своєї думки, поглиблює знання з обговорюваної проблеми.

Метою застосування технології «Дискусія в стилі телевізійного «токшоу» є отримання студентами навичок публічного виступу та дискутування, висловлення і захисту власної позиції, формування громадянської та особистої активності.

Метод «Дебати» - це один 3 найбільш складних способів обговорення дискусійних проблем. Дебати можна проводити лише тоді, коли студенти навчились працювати в групах та засвоїли технології вирішення проблем. У дебатах поділ на протилежні точки зору набуває найбільшої гостроти, оскільки студентам необхідно довго готуватись і публічно обгрунтовувати правильність своєї позиції. Важливо, щоб учасники дебатів не переносили емоції один на одного, а спілкувалися спокійно.

Висновки та перспективи подальших розвідок. Загалом, підсумовуючи ефективність перелічених форм організації спілкування на семінарських 
заняттях, слід особливо виокремити соціально значущий гуманістичний потенціал, який неодмінно трансформується через творчу працю в наступній діяльності майбутніх учителів початкових класів у демократичні когнітивні та поведінкові норми. Адже, як стверджують дослідники в галузі психології, кожна вища психічна функція в процесі розвитку з'являється двічі: спочатку як функція колективної поведінки, а згодом як спосіб індивідуальної поведінки, внутрішній процес діяльності. Отже, використання у ЗВО розглянутих інтерактивних методів навчання сприяє самореалізації особистості студентів, значно підвищує якість навчання i $\epsilon$ важливою «рушійною силою» професійного розвитку. Подальші дослідження вбачаємо у пошуках нових методів та технологій підготовки майбутніх учителів початкової школи, здатних до творчої роботи з учнями молодшого шкільного віку.

\section{СПИСОК ВИКОРИСТАНИХ ДЖЕРЕЛ:}

Фіцула, М. (2007). Педагогіка: навч.посіб. 2-ге вид. Київ: Академвидав. 560 с.

Антонів, Г. (2013). Особливості інтерактивного навчання. Школа: для заступників директорів і не тільки, 9, сс. 32-36.

Пометун, О. та Пироженко, Л. (2004). Сучасний урок. Інтерактивні технології навчання : наук.-метод. посібник. Київ: А.С.К., 192 с.

Пометун, О. (2007). Технологія інтерактивного навчання як інноваційне педагогічне явище. Рідна школа, 5, сс. 46-49.

Старинська, О. (2006). Розвиток інтелектуальної ініціативи засобами інтерактивного навчання. Рідна школа, 6, сс. 39-41.

Новолокова, Н. (2014). Технологія інтерактивного навчання. Педагогічна майстерня, 7, сс. 36-39.

Павелків, Р. та Цигипало, О. (2008). Дитяча психологія: навч. посіб. Київ: Академвидав, 432 с.

Кратясюк, Л. (2004). Інтерактивні методи навчання: (Розвиток комунікативних і мовних умінь). Дивослово, 10, сс. 2-11.

Косяк, Н. (2013). Інтерактивне навчання як інноваційне педагогічне явище. Відкритий урок: розробки, технології, досвід, 7-8, сс. 34-40.

Радченко, А. (2012). Ігрові методи та прийоми. Відкритий урок: розробки, технологіï, досвід, 10, сс. 47-49.

Комар, О. (2006). Навчання школярів за інтерактивними методами. Рідна школа, 5, сс. 57-60.

Коротаева, Е. (2014). Когда «интерактивные технологии» интерактивны? (О содержании и практической реализации профессионального стандарта педагога). Народное образование, 3, сс. 115-121.

Коваленко В. (2013). Мотивація - елемент інтерактивного навчання. Відкритий урок: розробки, технологї̈, досвід, 9, сс. 52-53.

Іванішена С. (2006). Форми та методи інтерактивного навчання. Початкова школа, 3, сс. 9-11.

\section{REFERENCES:}

Fitsula, M. (2007). Pedahohika: navch.posib. [Pedagogy: textbook]: 2-he vyd. Kyiv: Akademvydav. 560 s. [in Ukrainian].

Antoniv, H. (2013). Osoblyvosti interaktyvnoho navchannia [Peculiarities of Interactive Learning]. Shkola: dlia zastupnykiv dyrektoriv $i$ ne tilky, 9, ss. 32-36. [in Ukrainian]. 
Pometun, O. \& Pyrozhenko, L. (2004). Suchasnyi urok. Interaktyvni tekhnolohii navchannia : nauk.-metod. posibnyk [Modern Lesson. Interactive Learning Technologies: Science: method. manual]. Kyiv: A.S.K., 192 s. [in Ukrainian].

Pometun, O. (2007). Tekhnolohiia interaktyvnoho navchannia yak innovatsiine pedahohichne yavyshche [The technology of Interactive Learning as an Innovative Pedagogical Phenomenon]. Ridna shkola, 5, ss. 46-49. [in Ukrainian]

Starynska, O. (2006). Rozvytok intelektualnoi initsiatyvy zasobamy interaktyvnoho navchannia [Development of Intellectual Initiative through Means of Interactive Learning]. Ridna shkola, 6, ss. 39-41. [in Ukrainian]

Novolokova, N. (2014). Tekhnolohiia interaktyvnoho navchannia [Interactive Learning Technology] Pedahohichna maisternia, 7, ss. 36-39. [in Ukrainian]

Pavelkiv, R. \& Tsyhypalo, O. (2008). Dytiacha psykholohiia: navch. posib. [Child Psychology: teach. manual] Kyiv: Akademvydav, 432 s. [in Ukrainian]

Kratiasiuk, L. (2004). Interaktyvni metody navchannia: (Rozvytok komunikatyvnykh i movnykh umin) [Interactive Teaching Methods: (Development of Communicative and Linguistic Skills).]. Dyvoslovo, 10, ss. 2-11. [in Ukrainian].

Kosiak, N. (2013). Interaktyvne navchannia yak innovatsiine pedahohichne yavyshche [Interactive Learning as an Innovative Pedagogical Phenomenon]. Vidkrytyi urok: rozrobky, tekhnolohii, dosvid, 7-8, ss. 34-40. [in Ukrainian]

Radchenko, A. (2012). Ihrovi metody ta pryiomy [Game Techniques and Methods]. Vidkrytyi urok: rozrobky, tekhnolohii, dosvid, 10, ss. 47-49. [in Ukrainian].

Komar, O. (2006). Navchannia shkoliariv za interaktyvnymy metodamy [Teaching Students through Interactive Mmethods]. Ridna shkola, 5, ss. 57-60. [in Ukrainian]

Korotaeva, E. (2014). Kohda "interaktivnye tekhnologii" interaktivny? (O soderzhanii i prakticheskoi realizatsii professionalnogo standarta pedagoga) [When Are "Interactive Technologies" Interactive? (On the Content and Practical Implementation of the Professional Standard of the Teacher)।]. Narodnoje obrazovanije, 3, ss. 115-121. [in Russian]

Kovalenko V. (2013). Motyvatsiia - element interaktyvnoho navchannia [Motivation as an Element of Interactive Llearning]. Vidkrytyi urok: rozrobky, tekhnolohii, dosvid, 9, ss. 52-53. [in Ukrainian].

Ivanishena S. (2006). Formy ta metody interaktyvnoho navchannia [Forms and methods of interactive learning]. Pochatkova shkola, 3, ss. 9-11.[in Ukrainian]

\section{THE ROLE OF INTERACTIVE TEACHING TECHNOLOGIES IN PERSONAL-ORIENTED TRAINING OF ELEMENTARY SCHOOL FUTURE TEACHERS}

Tetiana Kolupaieva

Candidate of Pedagogical Sciences, Associate Professor, Professor at the Department of Primary Education Pedagogy, Rivne State University of the Humanities Rivne, Ukraine ORCID: 0000-0003-0164-0926 e-mail: kolupaeva.tatyana@gmail.com

Oksana Mischenya

Candidate of Pedagogical Sciences, Associate Professor, Associate Professor at the Department of Primary Education Pedagogy, Rivne State University of the Humanities 
Oksana Tretyak

Candidate of Pedagogical Sciences, Associate Professor at the Department of Primary Education Pedagogy, Rivne State University of the Humanities

Rivne, Ukraine

ORCID: 0000-0002-4558-2863

e-mail: ksenijat2017@gmail.com

\begin{abstract}
The acceleration of the pace of life, a large stream of knowledge that affects a modern person, requires from her the ability to find quickly the necessary solution, using the search methods for this, using a large number of different sources of information. In this regard, among the traditional forms and methods of teaching, interactive methods are increasingly used in pedagogical practice. The article is devoted to the role of interactive learning technologies in the person-oriented training of future teachers of elementary school. On the basis of analysis and generalization of pedagogical literature it was determined that interactive learning is a learning that takes place under the condition of constant, active interaction of all participants in the educational process. It is co-education, mutual learning (collective, group, learning in collaboration), where all participants are equal subjects of the educational process, they understand what they are doing, reflect on what they know, are able to carry out. The organization of interactive learning involves modeling various life situations, joint problem solving based on the analysis of circumstances and the situation, the use of role-playing games. The article particularly emphasizes the effectiveness of the listed forms of organization of communication at seminars, socially significant humanistic potential, which necessarily transforms through creative work in the next activity of future teachers of elementary school into democratic cognitive and behavioral norms.
\end{abstract}

Key words: interactive technologies of studies, personality-oriented education, discussion methods, group discussion, analysis of situations, playing techniques, educational games, creative games, role playing, organizational-activity games, interactive learning technology.

Стаття надійшла до редакиіï 12.03.2019 p. 